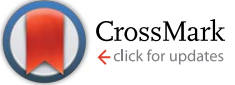

Cite this: RSC Adv., 2017, 7, 7406

Received 18th November 2016 Accepted 17th January 2017

DOI: $10.1039 / c 6 r a 27007 g$

www.rsc.org/advances

\section{Effects of $\mathrm{Mn}$-doped ceria oxygen-storage material on oxidation activity of diesel soot}

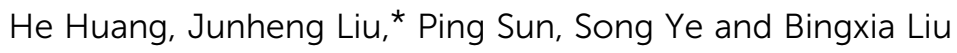

A Diesel Particulate Filter (DPF) is an effective device for reducing the soot emission of diesel engines. In order to realize the passive regeneration of DPF at low temperature, $\mathrm{Ce}_{1-x} \mathrm{Mn}_{x} \mathrm{O}_{2}$ catalysts doped with different doses of $\mathrm{Mn}$ were prepared through a sol-gel method. The influence of the catalyst on soot oxidation characteristics was studied by thermogravimetric analysis (TGA). The oxygen vacancy formation energy was calculated using the first principles Perdew-Wang 1991 (PW91) method based on density functional theory (DFT) within the generalized gradient approximation (GGA). Moreover, catalytic performance was evaluated using X-ray diffraction (XRD), scanning electron microscopy (SEM), Raman spectroscopy, $\mathrm{H}_{2}$-temperature programming reduction $\left(\mathrm{H}_{2}\right.$-TPR) and $\mathrm{X}$-ray photoelectron spectroscopy (XPS). The results show that the ignition temperature and peak temperature of soot oxidation gradually decrease, and also the activation energy of $\mathrm{Ce}_{1-x} \mathrm{Mn}_{x} \mathrm{O}_{2}$ for the catalytic soot oxidation decreases with the increase of $\mathrm{Mn}$ concentration. When the $\mathrm{Mn}$ concentration is $50 \%$, the ignition temperature and peak temperature are decreased by $42{ }^{\circ} \mathrm{C}$ and $32{ }^{\circ} \mathrm{C}$, respectively. The crystal structure of the prepared $\mathrm{Ce}_{1-x} \mathrm{Mn}_{x} \mathrm{O}_{2}$ has a better stability, and $\mathrm{Mn}$ doping leads to the increase of lattice defects. Moreover, the oxygen vacancy formation energy of the $\mathrm{Ce}_{1-x} \mathrm{Mn}_{x} \mathrm{O}_{2}$ catalyst decreases with increasing $\mathrm{Mn}$ concentrations. When $\mathrm{Mn}$ doping concentration is $50 \%$, the oxygen vacancy formation energy represents a minimum value of $0.31 \mathrm{eV}$.

\section{Introduction}

Diesel vehicles have received lots of attention globally due to their power efficiency and fuel economy. However, the pollutants in the exhaust gas, especially the soot emission, are a threat to the environment and to human health. ${ }^{1-3} \mathrm{~A}$ Diesel Particulate Filter (DPF) is an effective means to reduce the soot emission from diesel engines. A passive regeneration technique is used to reduce the activation energy of the soot oxidation with chemocatalysts. In this way, the soot can be burnt out with energy from the diesel exhaust to realize DPF regeneration. ${ }^{4,5}$ Therefore, the selection of catalyst is the key to DPF regeneration. Rare earth based catalysts are widely used in automotive exhaust purification catalysts, ceramics, rare earth polymers, fuel cells, coatings and many other fields because of their unique chemical and physical properties, which are represented by their abundant electronic energy level structure. Cerium dioxide $\left(\mathrm{CeO}_{2}\right)$, a high-performance rare earth material, is the core of the threeway catalyst used for automobile exhaust purification. $\mathrm{CeO}_{2}$ can simultaneously convert hydrocarbon (HC), carbon monoxide (CO) and nitrogen oxides $\left(\mathrm{NO}_{x}\right)$ from engine exhaust gas into $\mathrm{H}_{2} \mathrm{O}$, carbon dioxide $\left(\mathrm{CO}_{2}\right)$ and nitrogen $\left(\mathrm{N}_{2}\right)$. $\mathrm{CeO}_{2}$ is the core of oxygen storage/oxygen release materials, whose performance is

School of Automotive and Traffic Engineering, Jiangsu University, Zhenjiang 212013, China.E-mail: liujunheng365@163.com mainly determined by the redox ability of gas molecule, ${ }^{6,7}$ oxygen storage/oxygen release performance ${ }^{8-11}$ and oxygen transfer capability. ${ }^{10}$ When the oxygen content in the exhaust gas is high, $\mathrm{CeO}_{2}$ quickly store the oxygen and also releases oxygen in a timely fashion when oxygen content is low. Therefore, it can be referred to as "oxygen buffer". This function is essential for improving catalytic activity and prolonging the service life of the catalyst. ${ }^{11-17}$ However, pure $\mathrm{CeO}_{2}$ mainly has two defects. Firstly, there are very few oxygen defects of surface oxygen and bulk phase oxygen. Secondly, sintering occurs at high temperature, leading to the reduction in the capacity of oxygen storage and release. To increase the ability of oxygen storage/release and low temperature redox of the supported catalyst system, researchers normally doped $\mathrm{CeO}_{2}$ with a transition metal. ${ }^{18} \mathrm{Mn}$ mainly exists in the forms of changeable valence oxides such as $\mathrm{MnO}, \mathrm{MnO}_{2}, \mathrm{Mn}_{2} \mathrm{O}_{3}$ and $\mathrm{Mn}_{3} \mathrm{O}_{4}$, which is generally utilized as the electronic auxiliaries of catalysts. $\mathrm{Ce}_{1-x} \mathrm{Mn}_{x} \mathrm{O}_{2}$ catalyst formed by doping $\mathrm{Mn}$ into $\mathrm{CeO}_{2}$ can be used to promote some reactions. Wu et al. ${ }^{19,20}$ suggested that the doping of $\mathrm{Mn}$ into the internal lattice of $\mathrm{CeO}_{2}$ does not only improve the migration of reactive oxygen, but also enhance the overflow ability of lattice oxygen, which could strengthen the soot catalytic oxidation. Guillén-Hurtado et al. ${ }^{21}$ studied the mechanism of soot oxidation through cerium based catalyst by isotope pulse technique, and found that gaseous phase oxygen did not directly participate in soot oxidation. The active oxygen 
in the catalyst was firstly released and then migrated to the soot surface for oxidization. Meantime, the oxygen vacancies generated on the catalyst surface, adsorbed the gaseous phase oxygen into vacancy to supplement the consumed active oxygen. Thus, it can be said that, the active oxygen, oxygen vacancies, oxygen migration capability and other oxygen parameters play an important role in soot catalytic oxidation. Qi et al. ${ }^{22}$ prepared $\mathrm{MnO}_{x}-\mathrm{CeO}_{2}$ composite oxide by doping $\mathrm{Mn}$ into $\mathrm{CeO}_{2}$ system, which had high $\mathrm{NH}_{3}$-SCR (selective catalytic reduction) catalytic activity at low temperature. Delimaris et al. ${ }^{23,24}$ showed that the catalytic oxidation activity of $\mathrm{MnO}_{x}-\mathrm{CeO}_{2}$ to chlorinated volatile organic compounds (CVOCs) and volatile organic compounds (VOCs) was better than that of pure $\mathrm{CeO}_{2}$. However, there are still some debates about the decisive factors and the reaction path of soot catalytic oxidation. Most situ detection methods are directed at reactive oxygen species, but the real-time monitoring and analysis of oxygen vacancy are scarce.

Recently, new materials have been widely designed from studies at the level of atoms and molecules. This method combined with the experimental study, decreases the dependence on experimental instruments and also reduces the consumption of chemical reagents. Moreover, the catalytic reaction pathway and its mechanism can be further understood theoretically, so as to provide strong support for the designing and preparation of catalyst with good selectivity, high activity and strong anti-poisoning ability. However, there are very few reports of the influence of $\mathrm{Ce}_{1-x} \mathrm{Mn}_{x} \mathrm{O}_{2}$ on diesel soot oxidation.

In the current study, firstly, $\mathrm{Ce}_{1-x} \mathrm{Mn}_{x} \mathrm{O}_{2}$ catalysts doped with different $\mathrm{Mn}$ concentrations were prepared with sol-gel method. Secondly, X-ray diffraction (XRD), Raman spectrum, $\mathrm{H}_{2}$-temperature programming reduction $\left(\mathrm{H}_{2}\right.$-TPR $), \quad \mathrm{X}$-ray photoelectron spectroscopy (XPS) and thermogravimetric analysis (TGA) were used to characterize $\mathrm{Ce}_{1-x} \mathrm{Mn}_{x} \mathrm{O}_{2}$ catalyst and evaluate its oxidation activity. Finally, the first principle pseudopotential method based on the density functional theory (DFT $)^{25-28}$ was adopted to further study the $\mathrm{Ce}_{1-x} \mathrm{Mn}_{x} \mathrm{O}_{2}$ system doped with different Mn concentrations according to the crystal structure and oxygen vacancy. The object of this research is to systematically study the atomic structure and the oxygen vacancy formation energy of $\mathrm{Ce}_{1-x} \mathrm{Mn}_{x} \mathrm{O}_{2}$ catalyst, and reveal the microscopic mechanism of the improvement of the catalytic oxidation activity with $\mathrm{Mn}$-doped $\mathrm{CeO}_{2}$, which verifies experimental results.

\section{Experimental}

\subsection{Catalyst preparation}

$\mathrm{Ce}_{1-x} \mathrm{Mn}_{x} \mathrm{O}_{2}$ catalyst was prepared by sol-gel method in this research. Firstly, a certain amount of $\mathrm{Ce}\left(\mathrm{NO}_{3}\right)_{3} \cdot 6 \mathrm{H}_{2} \mathrm{O}$ (analytical grade, $\mathrm{AR}$ ) and $\mathrm{Mn}\left(\mathrm{NO}_{3}\right)_{2}(\mathrm{AR})$ were obtained with an electronic balance and added to citric acid to form the mixed liquor. The mixture was subjected to a water bath at $80^{\circ} \mathrm{C}$ and magnetically stirred until it forms into a gel. The gel, is then dried by air drying oven overnight, and roasted afterwards with a muffle furnace for 4 hours at $550{ }^{\circ} \mathrm{C}$. The Mn doping concentrations in this research were $12.5 \%, 25 \%$ and $50 \%$, and their corresponding chemical formulas were marked as $\mathrm{Ce}_{0.875} \mathrm{Mn}_{0.125} \mathrm{O}_{2}, \mathrm{Ce}_{0.75} \mathrm{Mn}_{0.25} \mathrm{O}_{2}$ and $\mathrm{Ce}_{0.5} \mathrm{Mn}_{0.5} \mathrm{O}_{2}$, respectively.

\subsection{Catalyst characterization}

The powder X-ray diffraction (XRD) patterns were recorded by a diffractometer (D8 ADVANCE, Bruker, Germany) operated at $40 \mathrm{kV}$ and $30 \mathrm{~mA}$, using nickel-filtered $\mathrm{Cu} \mathrm{K} \alpha$ radiation $(\lambda=$ $0.15418 \mathrm{~nm}$ ). The patterns were collected in a $2 \theta$ range from $20^{\circ}$ to $80^{\circ}$, with a scanning step of $4^{\circ} \mathrm{min}^{-1}$.

Scanning electron microscopy (SEM) image was carried out on a field emission scanning electron microscope S-4800 (Hitachi, Japan). Samples were coated with platinum to improve conductivity. The amplification range of the $S-4800$ was $20-8 \times 10^{5}$ times. The minimum resolution was $1.0 \mathrm{~nm}$, and the electron acceleration voltage range was $0.5-30 \mathrm{kV}$.

The Raman spectra of the samples were obtained with a Renishaw in Viat+Reflex spectrometer at room temperature and atmospheric pressure. A wavelength of $514.5 \mathrm{~nm}$ was used for the exciting source from $\mathrm{Ar}^{+}$ion laser. The power of the incident beam on the sample was $3 \mathrm{~mW}$. The wave number values of the Raman spectra were accurate to $2 \mathrm{~cm}^{-1}$.

$\mathrm{H}_{2}$-Temperature programming reduction $\left(\mathrm{H}_{2}\right.$-TPR $)$ was investigated on a Micromeritics AutoChemII2920. At the beginning of the tests, the catalysts were preoxidized in $1 \% \mathrm{O}_{2}$ / $\mathrm{He}\left(50 \mathrm{~mL} \mathrm{~min}{ }^{-1}\right)$ at $300{ }^{\circ} \mathrm{C}$ for $10 \mathrm{~min}$. Afterward they were cooled down to RT, flushed with He for $10 \mathrm{~min}$, and heated from $0{ }^{\circ} \mathrm{C}$ up to $550{ }^{\circ} \mathrm{C}$ in $10 \% \mathrm{H}_{2} / \mathrm{Ar}$ to finish the first TPR. The second TPR was performed subsequently, and a third TPR up to $800{ }^{\circ} \mathrm{C}$ was performed after another preoxidation process.

X-ray photoelectron spectra (XPS) were recorded using an ESCALAB $250 \mathrm{Xi}$ spectrometer with $\mathrm{Al} \mathrm{K} \alpha$ radiation $(1486.6 \mathrm{eV}$ ). The adventitious C 1s line at $284.8 \mathrm{eV}$ was used as an internal standard. The XPS core level spectra were analyzed in mixed Gaussian-Lorentzian peaks, using a shirley background subtraction.

\subsection{Catalytic testing}

The evaluation indicators of the catalytic activity mainly include soot ignition temperature $\left(T_{\mathrm{i}}\right)$ and peak temperature $\left(T_{\mathrm{m}}\right)$, among which $T_{\mathrm{i}}$ is defined as the temperature during which the total mass of the sample is reduced by $5 \%$ in the reaction, and $T_{\mathrm{m}}$ is the temperature corresponding to the maximum weightlessness rate. In the catalytic activity evaluation system, lower values of $T_{\mathrm{i}}$ and $T_{\mathrm{m}}$ represent better catalytic activity.

The test engine is a 4-cylinder, turbocharged, inter-cooled, electronic controlled common-rail diesel engine, and its main technical parameters are shown in Table 1. PM samples were collected under ESC 13-mode test cycle using the AVL SPC472 partial flow particle acquisition system. Thermogravimetric analysis (TGA) of particle sample was conducted on the METTLER TGA/DSC1 thermogravimetric analyzer, which has built-in high precision electronic balance and temperature sensor. In the thermogravimetric test, the sample weight was $3 \mathrm{mg}$, and the mass fraction of oxygen atmosphere was about $12 \%$, which was close to the oxygen content in the diesel exhaust. Highpurity $\mathrm{N}_{2}$ was taken as the protective gas, and its flow velocity 
Table 1 Diesel particles characteristic parameters of weightlessness

\begin{tabular}{llllll}
\hline & \multicolumn{2}{l}{$\begin{array}{l}\text { SOF } \\
\text { weightlessness } \\
\end{array}$} & & & \multicolumn{2}{l}{$\begin{array}{l}\text { Soot } \\
\text { weightlessness } \\
\left({ }^{\circ} \mathrm{C}\right)\end{array}$} & & & & \multicolumn{2}{l}{$\mathrm{C})$} & \\
\cline { 2 - 3 } & $T_{\mathrm{s}}$ & $T_{\mathrm{p}}$ & & $T_{\mathrm{i}}$ & $T_{\mathrm{m}}$ \\
\hline Sample & 173 & 301 & & 301 & 415 \\
$\mathrm{CeO}_{2}$ & 169 & 305 & & 283 & 409 \\
$\mathrm{Ce}_{0.875} \mathrm{Mn}_{0.125} \mathrm{O}_{2}$ & 171 & 297 & & 278 & 403 \\
$\mathrm{Ce}_{0.75} \mathrm{Mn}_{0.25} \mathrm{O}_{2}$ & 172 & 287 & & 259 & 383 \\
$\mathrm{Ce}_{0.5} \mathrm{Mn}_{0.5} \mathrm{O}_{2}$ & & & & &
\end{tabular}

was at a constant rate with $100 \mathrm{~mL} \mathrm{~min}^{-1}$. The programmed temperature range was $40-800{ }^{\circ} \mathrm{C}$, and the heating rate was kept at $15{ }^{\circ} \mathrm{C} \mathrm{min}^{-1}$. The collected diesel soot particles and catalyst were evenly mixed at the ratio of $4: 1$.

\section{Results and discussion}

\subsection{Activity tests}

Fig. 1 shows the results of the thermogravimetric (TG) experiments of diesel engine particles mixed with $\mathrm{Ce}_{1-x} \mathrm{Mn}_{x} \mathrm{O}_{2}$ catalysts with four different $\mathrm{Mn}$ doping concentrations. Compared with the pure $\mathrm{CeO}_{2}$, the weightlessness curves of the particle shift to the low temperature region with the increase of $\mathrm{Mn}$ doping concentration, which indicates that the particle ignition combustion temperature decreases. There are three obvious weightlessness peaks in the particle weightlessness rate curves under $\mathrm{Ce}_{1-x} \mathrm{Mn}_{x} \mathrm{O}_{2}$ catalysts, which are, in order, $\mathrm{HC}$ volatilization with low boiling point, HC oxidization with high boiling point and dry soot oxidative combustion. Its impact on the dry soot oxidation process is significant. With the increase of Mn in the doped proportion, the ignition temperature and peak temperature of the soot gradually decrease.

Table 1 lists the diesel particles weightlessness characteristic parameters under $\mathrm{Ce}_{1-x} \mathrm{Mn}_{x} \mathrm{O}_{2}$ catalysis. $T_{\mathrm{s}}$ is the temperature corresponding to the peak weight loss rate of the low boiling point $\mathrm{HC}$ in soluble organic fraction (SOF). $T_{\mathrm{p}}$ is the

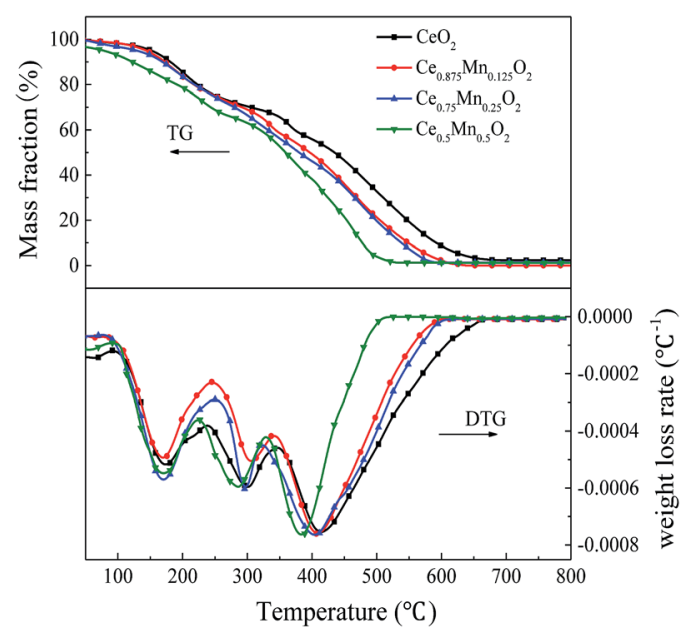

Fig. 1 TG and DTG curves of diesel particles. temperature corresponding to the peak weight loss rate of the high boiling point HC. $T_{\mathrm{i}}$ is the ignition combustion temperature of dry soot. $T_{\mathrm{m}}$ is the peak combustion temperature of dry soot. Compared with that of pure $\mathrm{CeO}_{2}$, the soot ignition combustion temperatures are decreased by 18,24 and $42{ }^{\circ} \mathrm{C}$, and the peak combustion temperatures are decreased by 6,12 and $32{ }^{\circ} \mathrm{C}$, respectively, when the Mn concentrations are $12.5 \%$, $25 \%$ and $50 \%$. This indicates that the effect of $\mathrm{CeO}_{2}$ on soot catalytic oxidation is obviously improved with doping $\mathrm{Mn}$, and the optimum Mn doping concentration is $50 \%$.

The kinetic parameters such as oxidation activation energy $(E)$ and pre-exponential factor $(A)$ of soot particles were analyzed by Coats-Redfern integral method. In this way, the relationship between the $\ln \left[\ln (1-\alpha) / T^{2}\right]$ and $1 / T$ of the diesel particles under the catalysis is obtained. The results of curve fitting are shown in Fig. 2. The linear regression coefficients of the fitted curves are all greater than 0.98 , and the fitting effect is ideal.

The activation energy and pre-exponential factor of each fitting curve are calculated as shown in Table 2 . It can be seen from Table 2 that compared with the pure $\mathrm{CeO}_{2}$, the activation energy of $\mathrm{Ce}_{1-x} \mathrm{Mn}_{x} \mathrm{O}_{2}$ for the catalytic soot oxidation reaction is significantly reduced, and the pre-exponential factor is increased. This indicates that Mn doping significantly increases the number of active sites on the surface of soot and catalyst, thus enhancing the catalytic activity of the catalyst on soot oxidation reaction. With the increase of Mn concentration, the activation energy decreases gradually and reaches the minimum when the Mn concentration is $50 \%$, which indicated that with the increase of Mn concentration, the energy required for soot oxidation reaction is gradually decreases, so that it is more easily oxidized, which is consistent with the thermogravimetric results.

\subsection{Catalyst characterization}

A series of characterizations were carried out to clarify the mechanism of soot catalytic oxidation through $\mathrm{Ce}_{1-x} \mathrm{Mn}_{x} \mathrm{O}_{2}$ catalyst on the microstructure. Fig. 3 gives the XRD profiles of the four $\mathrm{Ce}_{1-x} \mathrm{Mn}_{x} \mathrm{O}_{2}$ samples. $\mathrm{MnO}_{2}$ will transform into $\mathrm{Mn}_{2} \mathrm{O}_{3}$ oxide when it is calcined at $550{ }^{\circ} \mathrm{C}$. It can be seen that the characteristic diffraction peaks of $\mathrm{CeO}_{2}$ are detected in all samples. Compared with pure $\mathrm{CeO}_{2}$, the characteristic peaks are

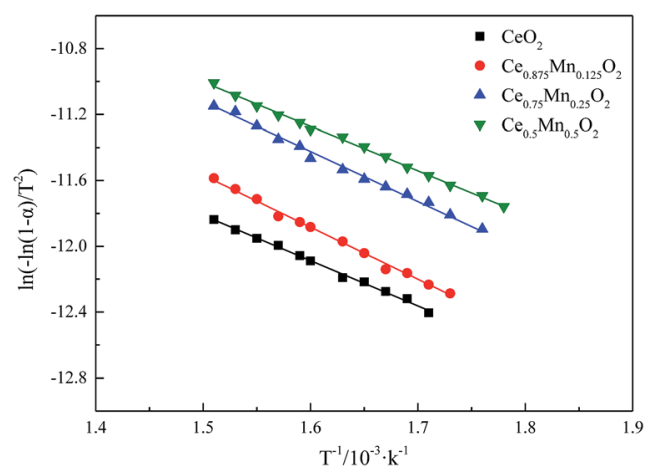

Fig. 2 Fitting curves of $\ln \left[-\ln (1-\alpha) / T^{2}\right]$ and of $1 / T$ particles under catalysis. 
Table 2 Effect of $\mathrm{Ce}_{1-x} \mathrm{Mn}_{x} \mathrm{O}_{2}$ catalyst on activation energy and preexponential factor

\begin{tabular}{lllll}
\hline Sample & $\begin{array}{l}\text { Fitting curve } \\
\text { equation }\end{array}$ & $\begin{array}{l}\text { Correlation } \\
\text { coefficient }\end{array}$ & $\begin{array}{l}E / \\
\left(\mathrm{kJ} \mathrm{mol}^{-1}\right)\end{array}$ & $\begin{array}{l}A / \\
\mathrm{min}^{-1}\end{array}$ \\
\hline $\mathrm{CeO}_{2}$ & $y=-3.17 x-6.82$ & 0.992 & 26.36 & 51 \\
$\mathrm{Ce}_{0.875} \mathrm{Mn}_{0.125} \mathrm{O}_{2}$ & $y=-3.16 x-6.81$ & 0.986 & 26.27 & 52 \\
$\mathrm{Ce}_{0.75} \mathrm{Mn}_{0.25} \mathrm{O}_{2}$ & $y=-3.09 x-6.77$ & 0.991 & 25.69 & 53 \\
$\mathrm{Ce}_{0.5} \mathrm{Mn}_{0.5} \mathrm{O}_{2}$ & $y=-2.99 x-6.66$ & 0.998 & 24.86 & 57 \\
\hline
\end{tabular}

still the main diffraction peaks of $\mathrm{Ce}_{1-x} \mathrm{Mn}_{x} \mathrm{O}_{2}$ catalyst, and the position of the peak is constant, but the intensity has been changed. It shows that the Mn doping does not change the crystal structure of cubic fluorite, and the structure is still stable. The characteristic peak of $\mathrm{Mn}_{2} \mathrm{O}_{3}$ also can be detected in the figure, which indicates that $\mathrm{Mn}$ ions have entered into $\mathrm{CeO}_{2}$ crystal lattice, forming solid solution. Due to difference in Mn electron scattering factor $\left(f_{\mathrm{Mn}}\right)$ and Ce electron scattering factor $\left(f_{\mathrm{Ce}}\right)$, the $\mathrm{CeO}_{2}$ material structure factor changes after being doped with Mn. Different Mn concentrations have different influence on the material structure factors $\left(f_{h k l}\right)$. The diffraction peak intensity $(I)$ is proportional to the material structure factors squared $\left(f_{h k l}^{2}\right)$, expressed as " $I \propto f_{h k l}^{2}$ ". This explains the diffraction peak intensity of the catalyst sample changes at different Mn doping concentrations.

The $\mathrm{Ce}_{1-x} \mathrm{Mn}_{x} \mathrm{O}_{2}$ catalyst had broader diffraction peaks than the pure $\mathrm{CeO}_{2}$ catalyst. Estimation of the lattice parameter by Rietveld refinement of the main diffraction peaks of the $\mathrm{CeO}_{2}$ phase demonstrated that $\mathrm{Ce}_{0.875} \mathrm{Mn}_{0.125} \mathrm{O}_{2}, \mathrm{Ce}_{0.75} \mathrm{Mn}_{0.25} \mathrm{O}_{2}$ and $\mathrm{Ce}_{0.5} \mathrm{Mn}_{0.5} \mathrm{O}_{2}$ shrank slightly by $0.543,0.534$ and $0.516 \mathrm{~nm}$, respectively. Slight downshift of the peaks indicated slight lattice contraction. ${ }^{29}$ The peak shift in the $\mathrm{Ce}_{1-x} \mathrm{Mn}_{x} \mathrm{O}_{2}$ sample was probably due to the difference between the radii of $\mathrm{Mn}^{2+}(0.067$ $\mathrm{nm})$ and $\mathrm{Ce}^{4+}(0.094 \mathrm{~m}){ }^{30}$ Introduction of lower-valence cations generated lattice strain and facilitated defect formation within the $\mathrm{CeO}_{2}$ lattice, which eventually improved extrinsic surface defects and resulted in superior soot oxidation performance.

The particle size in the unit area was analyzed by Nano Measure software in the SEM image to calculate the average

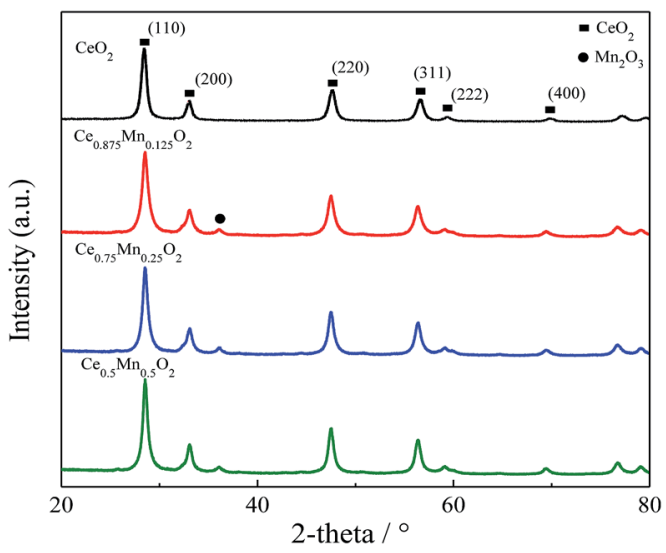

Fig. 3 XRD profiles of $\mathrm{Ce}_{1-x} \mathrm{Mn}_{x} \mathrm{O}_{2}$. particle size. Fig. 4 shows the SEM images of $\mathrm{Ce}_{1-x} \mathrm{Mn}_{x} \mathrm{O}_{2}$ samples. In Fig. 4(a), particle size range of nano- $\mathrm{CeO}_{2}$ is $30.1-55.2 \mathrm{~nm}$, with an average particle size is $43 \mathrm{~nm}$. In Fig. 4(b), particle size range of nano- $\mathrm{Ce}_{0.875} \mathrm{Mn}_{0.125} \mathrm{O}_{2}$ is $28.9-$ $47.1 \mathrm{~nm}$, with an average particle size is $38 \mathrm{~nm}$. In Fig. 4(c), particle size range of nano-Ce ${ }_{0.75} \mathrm{Mn}_{0.25} \mathrm{O}_{2}$ is $18.5-42.3 \mathrm{~nm}$, with an average particle size is $34 \mathrm{~nm}$. In Fig. 4(d), particle size range of nano- $\mathrm{Ce}_{0.5} \mathrm{Mn}_{0.5} \mathrm{O}_{2}$ is $15.5-40.3 \mathrm{~nm}$, with an average particle $d$ size is $31 \mathrm{~nm}$. The appearances of the three groups of particles are relatively uniform, which are mostly spherical or near spherical particles with clear boundaries. It proves that the particle aggregation is effectively controlled in the process of preparation, which makes the dispersion better.

Fig. 5 shows the Raman profiles of $\mathrm{CeO}_{2}$ doped with different Mn concentrations. As shown in the figure, all the $\mathrm{Ce}_{1-x} \mathrm{Mn}_{x} \mathrm{O}_{2}$ samples show a typical Raman vibration mode of $\mathrm{CeO}_{2}$. The vibration peaks of the four catalysts occur at $447 \mathrm{~cm}^{-1}$, which is the typical $\mathrm{F}_{2 \mathrm{~g}}$ vibration peak of $\mathrm{CeO}_{2}$ cubic fluorite structure. The offsets are very small and can be ignored. This indicates that $\mathrm{CeO}_{2}$ crystal structure does not change after being doped with $\mathrm{Mn}$, which is consistent with the results of XRD. There is a weak Raman vibration peak near $641 \mathrm{~cm}^{-1}$ for the doped $\mathrm{Mn}$ sample, which is the characteristic Raman vibration peak of Mn species. ${ }^{31}$ It can be seen that the Raman peak intensity with different Mn doping concentrations varies. The higher Raman peak intensity indicates the better crystallinity of $\mathrm{Ce}_{1-x} \mathrm{Mn}_{x} \mathrm{O}_{2}$. The peak widths at half height of the $\mathrm{F}_{2 \mathrm{~g}}$ Raman vibration peaks for the four catalysts are different, which corresponds to the particle size. This shows that Mn concentration affects the particle size of $\mathrm{Ce}_{1-x} \mathrm{Mn}_{x} \mathrm{O}_{2}$ catalyst. In addition to the $\mathrm{F}_{2 \mathrm{~g}}$ mode, two weak absorption peak emerged in the spectra of the Mn-containing catalyst: one at $351 \mathrm{~cm}^{-1}$, and another between $560 \mathrm{~cm}^{-1}$ and $600 \mathrm{~cm}^{-1}$, related to oxygen vacancies. ${ }^{32,33}$ Incorporation of $\mathrm{Mn}^{2+}$ into the $\mathrm{CeO}_{2}$ lattice may have created more oxygen vacancies and enhanced the OSC, which could improve the catalytic activity of $\mathrm{Ce}_{1-x} \mathrm{Mn}_{x} \mathrm{O}_{2}$ catalyst during soot oxidation.

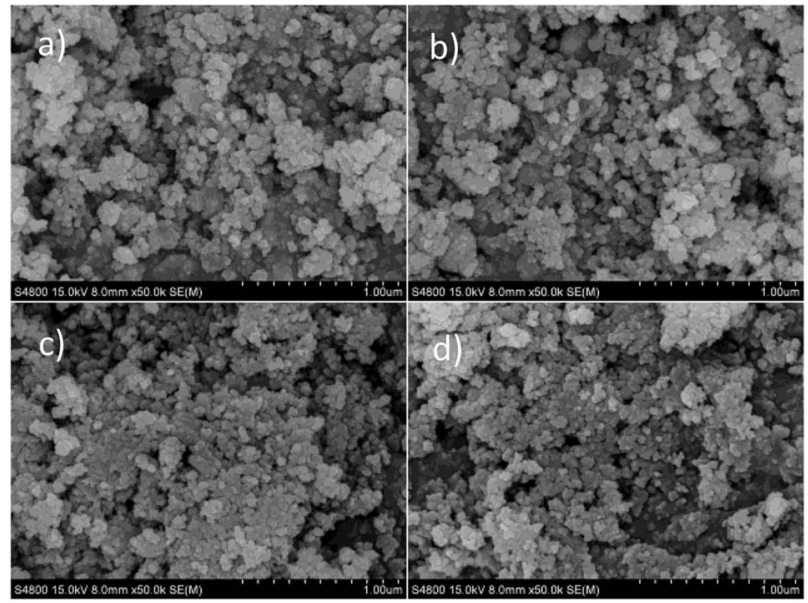

Fig. 4 SEM images of $\mathrm{Ce}_{1-x} \mathrm{Mn}_{x} \mathrm{O}_{2}$ sample: (a) $\mathrm{CeO}_{2}$; (b) $\mathrm{Ce}_{0.875} \mathrm{Mn}_{0.125} \mathrm{O}_{2}$; (c) $\mathrm{Ce}_{0.75} \mathrm{Mn}_{0.25} \mathrm{O}_{2}$; (d) $\mathrm{Ce}_{0.5} \mathrm{Mn}_{0.5} \mathrm{O}_{2}$ 


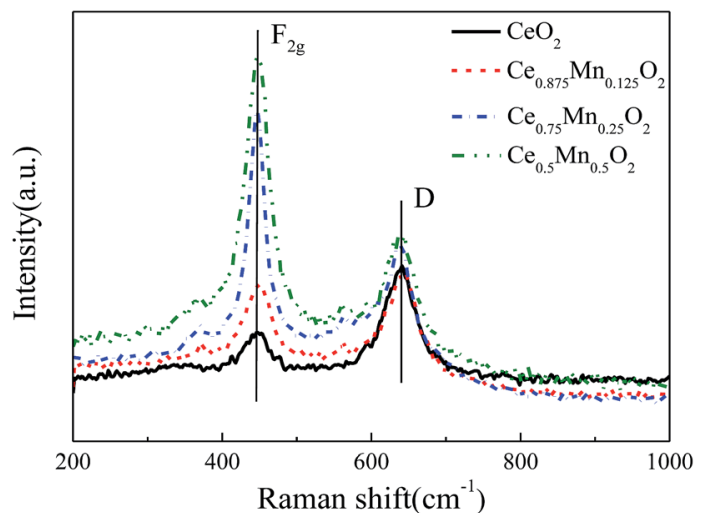

Fig. 5 Raman profiles of $\mathrm{Ce}_{1-x} \mathrm{Mn}_{x} \mathrm{O}_{2}$.

Fig. 6 shows the $\mathrm{H}_{2}$-TPR spectrogram of $\mathrm{Ce}_{1-x} \mathrm{Mn}_{x} \mathrm{O}_{2}$ catalyst. There are three obvious hydrogen consumption peaks as $\mathrm{CeO}_{2}$ catalyst is doped with $\mathrm{Mn}$, marked as $\alpha, \beta$ and $\gamma$. The oxygen desorption peak area of the catalyst is greatly improved after doping $\mathrm{Mn}$, changing the desorption temperature to a lower temperature. Therefore, both the oxidation reduction performance of the catalyst and the peak intensity increase with the increase of $\mathrm{Mn}$ content. The $\mathrm{Ce}_{0.5} \mathrm{Mn}_{0.5} \mathrm{O}_{2}$ reduction peaks at temperatures of $365{ }^{\circ} \mathrm{C}, 480{ }^{\circ} \mathrm{C}$ and $726{ }^{\circ} \mathrm{C}$ are the most obvious. Low temperature reduction peak $(\alpha)$ at $365{ }^{\circ} \mathrm{C}$ is the $\mathrm{Ce}_{0.5} \mathrm{Mn}_{0.5} \mathrm{O}_{2}$ surface adsorption oxygen reduction, the intermediate temperature reduction peak $(\beta)$ at $480{ }^{\circ} \mathrm{C}$ is the $\mathrm{Ce}_{0.5} \mathrm{Mn}_{0.5} \mathrm{O}_{2}$ surface lattice oxygen reduction, and the high temperature reduction peak $(\gamma)$ at $726{ }^{\circ} \mathrm{C}$ is the $\mathrm{Ce}_{0.5} \mathrm{Mn}_{0.5} \mathrm{O}_{2}$ bulk phase lattice oxygen reduction, while the pure $\mathrm{CeO}_{2}$ just has relatively weak reduction peaks of surface lattice oxygen and bulk phase lattice oxygen. The $\beta$-reduction peak areas of the three prepared $\mathrm{Ce}_{1-x} \mathrm{Mn}_{x} \mathrm{O}_{2}$ catalysts are larger than their $\alpha$ reduction peak areas, which indicate that they all have more surface lattice oxygen. Therefore, the $\mathrm{Mn}$-doped $\mathrm{CeO}_{2}$ increases the lattice defects and enrich the oxygen species, which is favorable for adsorption, migration and transformation of oxygen. The oxygen species of $\mathrm{Ce}_{1-x} \mathrm{Mn}_{x} \mathrm{O}_{2}$, especially the surface lattice oxygen, are directly related to its catalytic activity.

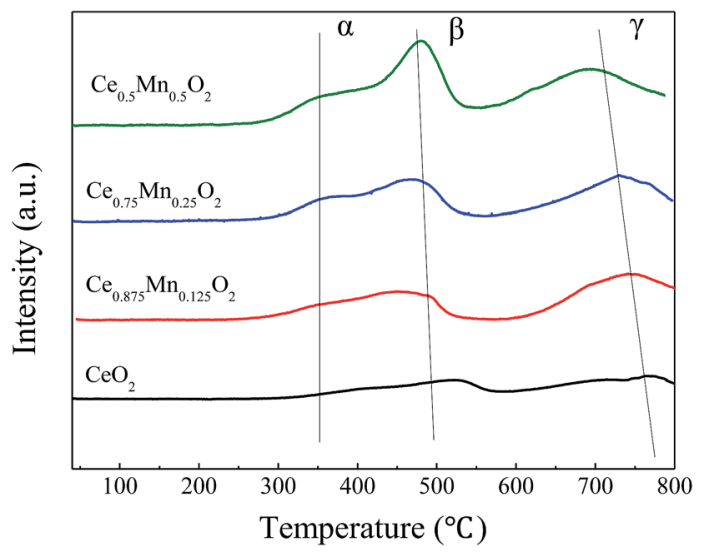

Fig. $6 \mathrm{H}_{2}$-TPR profiles of $\mathrm{Ce}_{1-x} \mathrm{Mn}_{x} \mathrm{O}_{2}$.
Stronger reduction capacity of the surface oxygen species can lead to higher catalytic activity.

Fig. 7(a) shows the XPS profiles of Mn 2p orbital for $\mathrm{Ce}_{1-x^{-}}$ $\mathrm{Mn}_{x} \mathrm{O}_{2}$ catalyst. There are two peaks at $642.2 \mathrm{eV}$ and $654.5 \mathrm{eV}$, which are the $2 \mathrm{p}_{3 / 2}$ peaks of $\mathrm{Mn}^{3+}$ and $\mathrm{Mn}^{4+}$ respectively. It indicates that $\mathrm{Mn}$ exists as +3 and +4 valences in the catalyst. The relative proportion of $\mathrm{Mn}^{4+}$ to $\mathrm{Mn}^{3+}$ increases with the increase of Mn content. Fig. 7(b) gives the XPS profiles of $\mathrm{O} 1 \mathrm{~s}$ orbital for $\mathrm{Ce}_{1-x} \mathrm{Mn}_{x} \mathrm{O}_{2}$ catalyst. It can be seen that each sample has a double-peak structure, which shows that the oxygen element exists on the catalytic surface in two forms. The peak with low electronic binding energy at $531.5 \mathrm{eV}$ is lattice oxygen $\left(\mathrm{O}_{\mathrm{I}}\right)$, and it is related to the redox property of the metal ion. The peak with high electronic binding energy at $529.5 \mathrm{eV}$ is adsorption oxygen $\left(\mathrm{O}_{\mathrm{II}}\right)$, also related to the oxygen vacancy concentration in the catalyst.

\subsection{DFT calculations}

The ideal crystal cell model of $\mathrm{CeO}_{2}$ is selected, where the Ce atom of $\mathrm{CeO}_{2}$ crystal cell is replaced by $\mathrm{Mn}$ atom to realize the displacement doping. For $\mathrm{Ce}_{1-x} \mathrm{Mn}_{x} \mathrm{O}_{2}$ system with different doping concentrations, supercell models with different atomic numbers $(6,12,24)$ are firstly established. Then, $\mathrm{Mn}$ atom is used to replace Ce atom in the supercell to simulate different doping concentrations. Calculations show that, the super cell atomic numbers of 6,12 and 24 corresponds to Mn concentrations of $50 \%, 25 \%$ and $12.5 \%$, respectively. Fig. 8 gives schematic cell models of $\mathrm{CeO}_{2}$ and Mn-doped with 25\% concentration.

The DFT calculations corrected by on-site coulomb interaction were performed by using the Perdew-Wang 1991 (PW91) GGA approach. ${ }^{34}$ Firstly, the unit cell structure was conducted with geometry optimization. The cut-off energy was set as $360 \mathrm{eV}$, and self-consistent field energy convergence criterion was $1.0 \times 10^{-6} \mathrm{eV}$. The optimal convergence energy was smaller than $1.0 \times 10^{-3} \mathrm{eV}$, and the force threshold was set to $0.5 \mathrm{eV}$ $\AA^{-1}$. The vacuum gap was set to $10 \AA$.

The oxygen vacancy formation energy is as an important indicator used to measure the catalytic activity of the catalyst. The decrease in oxygen vacancy formation energy shows that
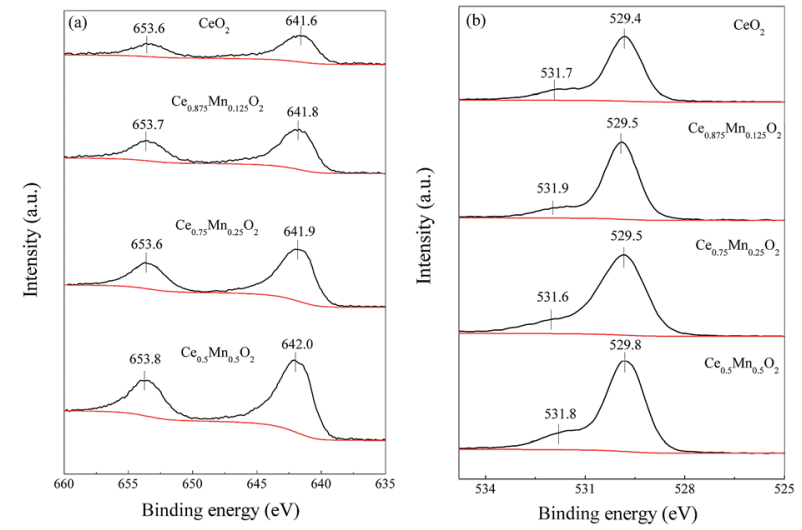

Fig. 7 XPS spectra of $\mathrm{Ce}_{1-x} \mathrm{Mn}_{x} \mathrm{O}_{2}$, (a) $\mathrm{Mn} 2 \mathrm{p}$, (b) $\mathrm{O} 1 \mathrm{~s}$. 

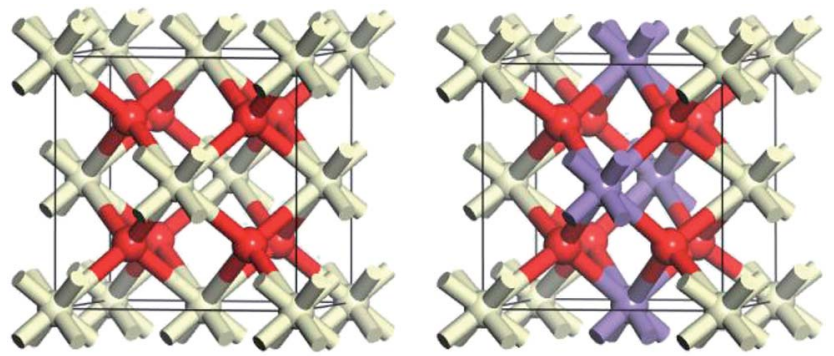

\section{$\bigcirc_{\text {ce }} \odot_{\mathrm{Mn}}$}

Fig. 8 Schematic cell model of $\mathrm{CeO}_{2}$ and $\mathrm{Mn}$-doped $\left(\mathrm{Ce}_{0.75} \mathrm{Mn}_{0.25} \mathrm{O}_{2}\right)$.

the oxygen release ability of the catalyst is improved. It is defined as follows:

$$
E_{\mathrm{V}}=E_{\mathrm{CeO}_{2} / \mathrm{Mn}}-\left(E_{\mathrm{VCeO}_{2}}+E_{\mathrm{O}}\right)
$$

where $E_{\mathrm{CeO}_{2} / \mathrm{Mn}}$ is the supercell energy after doping with $\mathrm{Mn}$. $E_{\mathrm{VCeO}_{2}}$ is the supercell energy with the absence of one oxygen atom. $E_{\mathrm{O}}$ is the energy of a single oxygen atom.

Table 3 lists the lattice constants of the optimized pure $\mathrm{CeO}_{2}$ and the $\mathrm{CeO}_{2}$ doped with different $\mathrm{Mn}$ concentrations. The calculated value of $0.547 \mathrm{~nm}$ is in agreement with experimental value of $0.541 \mathrm{~nm},{ }^{35}$ which verifies the reliability of the selected model. After doping with $\mathrm{Mn}$, the lattice constant of $\mathrm{Ce}_{1-x^{-}}$ $\mathrm{Mn}_{x} \mathrm{O}_{2}$ is slightly smaller than that of pure $\mathrm{CeO}_{2}$, and it monotonously decreases with the increase of Mn content. This phenomenon is due to the replacement of the ionic radius of $\mathrm{Ce}^{3+}(0.101 \mathrm{~nm})$ or $\mathrm{Ce}^{4+}$ with the ionic radius of $\mathrm{Mn}^{2+}$, because the ionic radius of $\mathrm{Mn}^{2+}$ is smaller than that of $\mathrm{Ce}^{4+}$ and $\mathrm{Ce}^{3+}$, resulting in a smaller bond length of $\mathrm{Mn}-\mathrm{O}$ than $\mathrm{Ce}-\mathrm{O}$.

Due to less $\mathrm{Mn}$ entering into $\mathrm{CeO}_{2}$ lattice in the case of low $\mathrm{Mn}$ doping concentration, the bulk oxygen concentration decrease, and the total cation concentration also decrease, which further reduce the oxygen storage capacity. It shows that there are two kinds of oxygen storage mechanisms in the $\mathrm{Ce}_{1-x} \mathrm{Mn}_{x} \mathrm{O}_{2}$ system that influences each other, which are surface phase oxygen storage and bulk phase oxygen storage. Calculations indicate that $\mathrm{Mn}$ can better enter into $\mathrm{CeO}_{2}$ lattice when Mn concentration is $50 \%$, forming solid solution with high structure stability, which significantly increases the oxygen storage capacity.

Fig. 9 shows the oxygen vacancy formation energy of $\mathrm{Ce}_{1-x^{-}}$ $\mathrm{Mn}_{x} \mathrm{O}_{2}$ catalyst at different $\mathrm{Mn}$ doping concentrations. The oxygen vacancy formation energy in pure $\mathrm{CeO}_{2}$ system is

Table 3 Optimized lattice parameters of $\mathrm{Ce}_{1-x} \mathrm{Mn}_{x} \mathrm{O}_{2}$

\begin{tabular}{llll}
\hline Sample & $a(\mathrm{~nm})$ & $b(\mathrm{~nm})$ & $c(\mathrm{~nm})$ \\
\hline $\mathrm{CeO}_{2}$ & 0.547 & 0.547 & 0.547 \\
$\mathrm{Ce}_{0.875} \mathrm{Mn}_{0.125} \mathrm{O}_{2}$ & 0.542 & 0.543 & 0.544 \\
$\mathrm{Ce}_{0.75} \mathrm{Mn}_{0.25} \mathrm{O}_{2}$ & 0.534 & 0.534 & 0.532 \\
$\mathrm{Ce}_{0.5} \mathrm{Mn}_{0.5} \mathrm{O}_{2}$ & 0.516 & 0.513 & 0.513
\end{tabular}

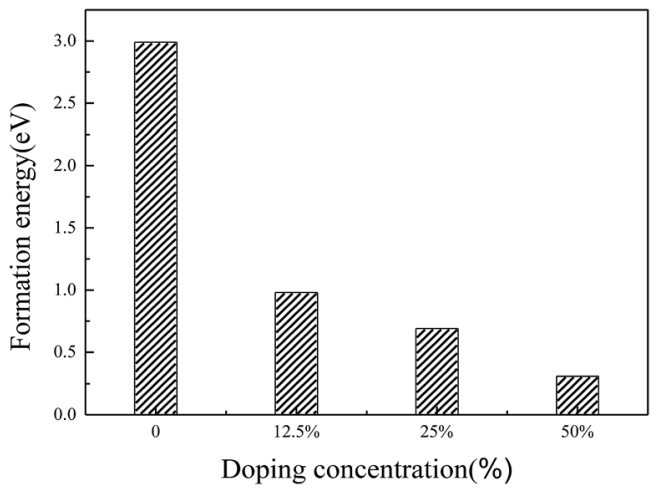

Fig. 9 Oxygen vacancy formation energy of $\mathrm{Ce}_{1-x} \mathrm{Mn}_{x} \mathrm{O}_{2}$.

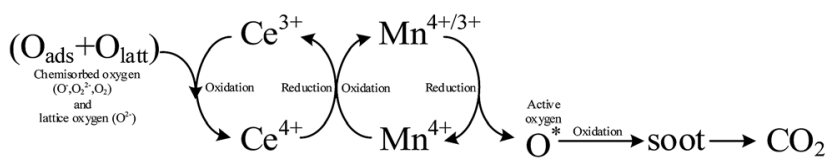

Fig. 10 Illustration of catalytic effect of $\mathrm{Ce}_{1-x} \mathrm{Mn}_{x} \mathrm{O}_{2}$.

$2.99 \mathrm{eV}$, which is consistent with the research results of Yang et al. ${ }^{35}$ The oxygen vacancy formation energy in $\mathrm{CeO}_{2}$ is greatly reduced with doping $\mathrm{Mn}$, showing that with Mn-doped, the oxygen release ability can be significantly improved. The oxygen vacancy formation energy of $\mathrm{Ce}_{1-x} \mathrm{Mn}_{x} \mathrm{O}_{2}$ catalyst decreases with the increase of $\mathrm{Mn}$ doping content, which indicates that the Mn substitution eases the formation of oxygen vacancies and realizes the transformation of $\mathrm{Ce}^{4+} \leftrightarrow \mathrm{Ce}^{3+}$. Fig. 9 also shows that when the Mn doping concentration is $50 \%$, the oxygen vacancy formation energy represents a minimum value of $0.31 \mathrm{eV}$. Meantime, its oxygen storage/oxygen release capacity is the most excellent. The results are in agreement with the results of the thermogravimetric experiments shown in Fig. 1.

\subsection{Catalytic mechanism}

The catalytic effect of $\mathrm{Ce}_{1-x} \mathrm{Mn}_{x} \mathrm{O}_{2}$ catalyst is illustrated in Fig. 10, showing that the presence of cerium oxide enhances oxygen mobility in the reaction cycle. Meanwhile, small particle size also facilitates oxygen mobility from interior to surface within nano-crystallite. Interaction in $\mathrm{Ce}-\mathrm{Mn}$ oxides can be regarded as an oxygen transition process from lattice oxygen $\left(\mathrm{O}_{\text {latt }}\right)$ and chemisorbed oxygen $\left(\mathrm{O}_{\text {ads }}\right)$ to active $\mathrm{O}^{*}$ on the active sites of catalyst surface, which is favorable for the soot oxidation. In the redox cycle, $\mathrm{Ce}^{4+} / \mathrm{Ce}^{3+}$ redox couple features in oxygen storage, that is, $\mathrm{CeO}_{2}$ acts as an oxygen buffer by storing/ releasing oxygen species due to $\mathrm{Ce}^{4+} / \mathrm{Ce}^{3+}$ redox, ${ }^{36}$ which facilitates the mobility of oxygen in the redox cycle.

\section{Conclusions}

With the increase of Mn doping concentrations, the weightlessness curves of diesel engine particles move towards low temperature regions, gradually decreasing the corresponding ignition temperature, peak temperature and the activation 
energy of $\mathrm{Ce}_{1-x} \mathrm{Mn}_{x} \mathrm{O}_{2}$ for the catalytic soot oxidation. Compared with pure $\mathrm{CeO}_{2}$, the soot ignition combustion temperatures are decreased by 18,24 and $42{ }^{\circ} \mathrm{C}$, and the peak temperatures are decreased by 6,12 and $32{ }^{\circ} \mathrm{C}$, when the $\mathrm{Mn}$ concentrations are $12.5 \%, 25 \%$ and $50 \%$, respectively. It shows that the oxidation activity of $\mathrm{Ce}_{1-x} \mathrm{Mn}_{x} \mathrm{O}_{2}$ catalyst doped with Mn has obviously improved.

Characterization results from XRD and Raman show that the three groups of the prepared $\mathrm{Ce}_{1-x} \mathrm{Mn}_{x} \mathrm{O}_{2}$ catalysts still have the crystal structure of cubic fluorite and their structures are stable. Mn-doped $\mathrm{CeO}_{2}$ can improve its dispersion, increase the lattice defects and enrich the oxygen species, which is beneficial to the oxygen adsorption, oxygen migration and oxygen transformation.

The $\mathrm{CeO}_{2}$ lattice constant calculated through GGA-PW91 of DFT is close to the experimental value, which verifies the reliability of this simulation method. Calculations show that Mn can better enter into $\mathrm{CeO}_{2}$ lattice and form a solid solution with high structure stability when Mn doping concentration is $50 \%$.

For $\mathrm{CeO}_{2}$ catalyst, $\mathrm{Mn}$-doped can greatly reduce oxygen vacancy formation, improve the ability of oxygen release and enhance its redox capacity. When the Mn doping concentration is $50 \%$, the oxygen vacancy formation energy can be minimized to $0.31 \mathrm{eV}$, and it would be very conducive to soot catalytic oxidation capacity of diesel engines.

\section{Acknowledgements}

We would like to acknowledge the financial supports from the Natural Science Major Research Project of Jiangsu province university (14KJA470001), State Key Laboratory of Engines, Tianjin University (K2016-05), Natural Science Foundation of Jiangsu Province, China (BK20160538), the Graduate Student Scientific Research Innovation Project of Jiangsu province university (KYLX_1038) and the Priority Academic Program Development of Jiangsu Higher Education Institutions (PAPD).

\section{Notes and references}

1 A. Bueno-Lopez, Appl. Catal., B, 2014, 146, 1-11.

2 L. Pahalagedara, H. Sharma, C. H. Kuo, S. Dharmarathnat and A. Joshi, Energy Fuels, 2012, 26, 384-388.

3 Y. Sekine, H. Koyama, M. Matsukata and E. Kikuchi, Fuel, 2013, 103, 2-6.

4 S. Chatterjee, R. Conway, S. Viswanathan, M. Blomquist, B. Klueseuer and S. Anderson, $N O_{x}$ and PM control from heavy duty diesel engines using a combination of low pressure EGR and continuously regenerating particulate filter, SAE Paper no. 01-0048, 2003.

5 M. Mohr, A. M. Forss and U. Lehmann, Environ. Sci. Technol., 2006, 40, 2375-2383.

6 W. C. Zhan, X. Y. Zhang, Y. L. Guo, L. Wang and Y. Guo, J. Rare Earths, 2014, 32, 146-152.

7 T. F. Hou, Y. S. Lei, S. Y. Zhang, J. H. Zhang and W. J. Cai, J. Rare Earths, 2015, 33, 42-45.

8 Z. M. Shi, Y. Liu, W. Y. Yang, K. M. Liang, F. Pan and S. R. Gu, J. Eur. Ceram. Soc., 2002, 22, 1251-1256.
9 H. Huang, J. H. Liu, P. Sun and S. Ye, $R S C A d v ., 2016,104,28-$ 34.

10 E. Aneggi, M. Boaro, C. D. Litenburg, G. Dolcetti and A. Trovarelli, J. Alloys Compd., 2006, 37, 1096-1102.

11 H. X. Mai, L. D. Sun, Y. W. Zhang, R. Si and W. Feng, J. Phys. Chem., 2005, 109, 24380-24385.

12 F. Lin, W. Y. Huang, J. Y. Tang and P. D. Yang, Nano Res., 2011, 4, 61-71.

13 J. Kaspar, P. Fomasiero and M. Graziani, Catal. Today, 1999, 50, 285-298.

14 M. Sugiura, M. Ozawa, A. Suda, T. Suzuki and T. Kanazawa, Bull. Chem. Soc. Jpn., 2005, 78, 752-767.

15 Z. M. Shi, Y. Liu, W. Y. Yang, K. M. Liang and F. Pan, J. Eur. Ceram. Soc., 2002, 22, 1251-1256.

16 G. Dutta, T. Baidya, M. S. Hegde, K. R. Priolkar and P. R. Sarode, J. Am. Chem. Soc., 2006, 18, 3249-3256.

17 E. M. And, T. Egami, R. B. And, M. Koranne and S. Tyadi, J. Phys. Chem. B, 2000, 104, 11110-11116.

18 A. Trovarelli and P. Fornasiero, Catalysis by Ceria and Related Materials, Imperial College Press, London, 2002.

19 X. Wu, S. Liu, W. Duan, F. Lin and R. Ran, J. Hazard. Mater., 2011, 187, 283-290.

20 Q. Liang, X. Wu, D. Weng and H. Xu, Catal. Today, 2008, 139, 113-118.

21 N. Guillén-Hurtado, A. García-García and A. Bueno-López, J. Catal., 2013, 299, 181-187.

22 G. Qi, R. T. Yang and R. Chang, Appl. Catal., B, 2004, 51, 93106.

23 L. Shi, X. Wang, Q. Zhao, Y. Zhang and L. Zhang, Catal. Commun., 2009, 86, 166-175.

24 D. Delimaris and T. Ioannides, Appl. Catal., B, 2009, 89, 295302.

25 P. Ryderg, F. S. Jorgensen and L. Olsen, Expet Opin Drug Metabol Toxicol, 2014, 10, 215-227.

26 W. Kohn, A. D. Becke and R. G. Parr, J. Phys. Chem., 1996, 31, 12974-12980.

27 N. H. March, G. G. N. Angilella and R. Pucci, Int. J. Mod. Phys. $B, 2013,27,5814-5821$.

28 P. Junell, K. Honkala, M. Hirsimaki, M. Valden and K. Laasonen, Surf. Sci., 2003, 546, 797-802.

29 P. Sudarsanam, B. Mallesham, D. N. Durgasri and B. M. Reddy, RSC Adv., 2014, 4, 11322-11330.

30 Y. Zuo, L. Li, X. Huang and G. Li, Catal. Sci. Technol., 2013, 4, 402-410.

31 Y. F. Qu, J. X. Guo, Y. H. Chu, M. C. Sun and H. Q. Yin, Appl. Surf. Sci., 2013, 282, 425-431.

32 L. F. Nascimento and O. A. Serra, Process Saf. Environ. Prot., 2016, 101, 134-143.

33 O. H. Laguna, M. A. Centeno, F. R. Sarria and J. A. Odriozola, Catal. Today, 2011, 172, 118-123.

34 M. L. Fu, J. M. Lin, W. B. Zhu, J. L. Wu and L. M. Chen, J. Rare Earths, 2014, 33, 153-158.

35 Z. X. Yang, T. K. Woo and K. Hermansson, J. Chem. Phys., 2006, 124, 579-593.

36 G. Liu, R. L. Yue, Y. Jia, Y. Ni, J. Yang, H. D. Liu and Z. Wang, Particuology, 2013, 11, 454-459. 